\title{
A comparison of chemical MSW compositional data between China and Denmark
}

\author{
Yang, Na; Damgaard, Anders; Scheutz, Charlotte; Shao, Li Ming; He, Pin Jing
}

Published in:

Journal of Environmental Sciences

Link to article, DOI:

10.1016/j.jes.2018.02.010

Publication date:

2018

Document Version

Peer reviewed version

Link back to DTU Orbit

Citation (APA):

Yang, N., Damgaard, A., Scheutz, C., Shao, L. M., \& He, P. J. (2018). A comparison of chemical MSW compositional data between China and Denmark. Journal of Environmental Sciences, 74, 1-10.

https://doi.org/10.1016/j.jes.2018.02.010

\section{General rights}

Copyright and moral rights for the publications made accessible in the public portal are retained by the authors and/or other copyright owners and it is a condition of accessing publications that users recognise and abide by the legal requirements associated with these rights.

- Users may download and print one copy of any publication from the public portal for the purpose of private study or research.

- You may not further distribute the material or use it for any profit-making activity or commercial gain

- You may freely distribute the URL identifying the publication in the public portal

If you believe that this document breaches copyright please contact us providing details, and we will remove access to the work immediately and investigate your claim. 
A comparison of chemical MSW compositional data between

\section{China and Denmark}

Na Yang ${ }^{\text {a,c }}$, Anders Damgaard ${ }^{b}$, Charlotte Scheutz ${ }^{b}$, Li-Ming Shao ${ }^{d}$, Pin-Jing He ${ }^{c^{*}, d}$

4

a Shenzhen Academy of Environmental Sciences, 50 Honggui Road, Shenzhen 518001, China

6

b Department of Environmental Engineering, Technical University of Denmark, 2800, Kongens Lyngby, Denmark

${ }^{c}$ State Key Laboratory of Pollution Control and Resource Reuse, Tongji University, 1239 Siping Road, Shanghai 200092, China.

${ }^{\mathrm{d}}$ Institute of Waste Treatment and Reclamation, Tongji University, 1239 Siping Road, Shanghai 200092, China 
Chemical waste compositions are important for municipal solid waste management, as they determine the pollution potentials from different waste strategies. A representative dataset for chemical characteristics of individual waste fractions is frequently required to assess chemical waste composition, but it is usually reported in developed countries and not in developing countries. In this study, a dataset for Chinese waste was established through careful data screening and assessment, named as $\mathrm{CN}$ dataset. Meanwhile, a dataset for Danish waste (DK dataset) was also summarized based on previous studies. In order to quantitatively evaluate the reliabilities of $\mathrm{CN}$ and $\mathrm{DK}$ datasets, the chemical waste compositions in four Chinese cities were estimated by utilizing both of them, respectively. It is indicated that the usage of CN datasets led to significantly lower discrepancies from the actual values based on laboratory analysis in most cases. Within the datasets, the moisture contents of food waste, paper, textiles, and plastics, the carbon content of food waste, as well as the oxygen content of plastics would induce significant divergences, which should be paid special attention when gathering the information. In addition, the fractional waste compositions in China showed similar features with other developing countries but differ significantly with developed countries. Thus the above-mentioned conclusions could also be true in other developing countries.

\section{Keywords}

Municipal solid waste, chemical composition, moisture content, water diffusion, consumption and dietary habits, estimation method 
Due to the rapid growth in the amounts of municipal solid waste (MSW) in developing countries, many large cities are faced with a "garbage siege," whereby waste dumping sites originally located far outside the conurbations are now surrounding these rapidly expanding cities, resulting in significant human and environmental impacts ( $\mathrm{Hu}$ et al., 2012; $\mathrm{Wu}$ and $\mathrm{Xu}$, 2013). To design a proper waste management system with reduced environmental impacts, knowledge of waste properties is important (Cleary, 2009). Waste properties are often described in terms of fractional waste compositions and chemical waste compositions. Fractional compositions determine the potential for recycling and energy recovery (Tai et al., 2011), while chemical compositions are essential for estimating pollutant potentials from different waste strategies (Manfredi et al., 2011; Yang et al., 2012; Yang et al., 2013). For example, higher plastic content will increase the heating values of MSW and subsequently make it more effective to recover energy by incineration. However, the fossil carbon contained in plastic fractions would induce higher greenhouse gas (GHG) emissions when MSW is incinerated (Yang et al., 2012). and change over time, due to economic development, waste management policies, and energy supplies (Wang and Nie, 2001; Wei et al., 1997). Correspondingly, chemical waste compositions also change owing to the varied contributions of waste fractions. The chemical compositions of mixed waste can be measured by laboratory analysis (He et al., 2010; Huang et al., 2003; Zhang et al., 2009) or be calculated by combining fractional waste compositions in specific scenarios and the general chemical characteristics of individual fractions (Yang et al., 2012; Zhao et al., 2009a; Zhao et al., 2011; Zhao et al., 2009b). Fractional waste compositions can be obtained by on-site sorting and weighing, which is frequently conducted due to low technical requirements (Ministry of Housing and Urban-Rural Development of the People's Republic of China, 2009).

60 Laboratory analyzes of the chemical compositions of mixed waste are rarely reported in 61 developing countries, as the sample preparation and analysis is labor-intensive and requires technical knowhow and analytical facilities. The same situation occurs for the chemical 
characteristics of individual fractions, which conversely often refer to existing datasets. Generally, the chemical characteristics of individual fractions consist of major parameters, e.g. moisture content, organic element content, heating values, and trace parameters, the latter of which usually refer to heavy metal content (Zhang et al., 2008). Heavy metals are usually contained in just a few specific items, for example over $90 \%$ of cadmium and mercury in MSW comes from batteries (Riber et al., 2009). The availability or non-availability of these materials in the waste can significant induce the differences in heavy metal content. It is thus hard to estimate heavy metal content by employing the aforementioned methods. In existing studies, major parameters are often taken into account, whereas trace parameters are often left out. For this study, the major parameters are termed as "chemical characteristics" due to their data availability.

Presently, datasets for the chemical characteristics of individual fractions are extremely scarce. A series of chemical characteristics often referred to was from the handbook written by Tchobanoglous et al. (1993), modified from data obtained in 1966 based on waste in the USA (Kaiser, 1966). In 2007, a comprehensive study focusing on the chemical characteristics of household waste was performed in Denmark (Lagerkvist et al., 2011; Riber et al., 2009), the results of which are available through the EASETECH software package (Clavreul et al., 2014), a widely used tool for life cycle assessment of waste management. In the case of developing countries, there are no comprehensive studies published in this research field. Taking China as an example, researchers (Zhao et al., 2009a; Zhao et al., 2011; Zhao et al., 2009b) tend to refer to chemical characteristics reported in Western countries (Tchobanoglous et al., 1993). However, this may lead to mis-estimation of chemical compositions. For example, the moisture content of mixed MSW in Hangzhou, estimated by refering to Tchobanoglous et al. (1993), i.e. 43.2\% (Zhao et al., 2009b), was remarkably lower than the actual measured values, i.e. $57.5 \%$ (Ni and Hong, 2005) and 56.5\% (Zhuang et al., 2008), which could evoke subsequent incorrect findings in relation to heating values and the leachate generation potential of waste.

The primary aim of this study was to compile waste property data reported for Chinese cities, including fractional waste compositions, chemical waste compositions, and chemical 
91 characteristics of individual waste fractions. Fractional waste compositions in developing 92 countries were additionally compared with those in developed countries and the causes of these differences were identified. The Chinese dataset was finally compared with a Danish dataset, by applying the data to four Chinese cities and contrasting the differences in results between the two datasets.

\section{Data Source and Approaches}

\subsection{Fractional waste compositions}

Fractional waste compositions for 18 Chinese cities were compiled (see details in Table 1). Datasets for megacities as well as smaller cities, and with a certain geographical distribution, are included. Datasets published in the last decade were preferred to older data. Since fractional waste compositions are potentially used for designing waste treatment systems, data were obtained for the remaining mixed waste after source-segregating recyclables in residential areas or waste treatment plants, rather than the originally generated waste in house. Most of the results were average values based on long-term monitoring, while only a few were based on one-time sampling. To be consistent across individual studies and to allow for comparison, the waste was defined to consist of the following eight fractions: Food waste, paper, wood, textiles, plastics, non-combustibles, glass, and metal.

Fractional waste compositions for China were compared to fractional waste composition data for 12 other developing countries and nine developed countries, which were also compiled from published papers (Table S1 in the supporting information). The eight waste fractions were classified into three main groups according to the degradation velocity, which allowed for a comparison of fractional composition via a ternary diagram between Chinese cities and compositions in other countries. The three degradation groups were: Fast Degradable (FD), represented by food waste, Slowly Degradable (SD), consisting of paper, wood, and textiles, and Non-Degradable (ND), consisting of plastics, non-combustibles, glass, and metal. The degradation velocity was used as the classification criterion, because it determined the performance of waste fractions during treatment processes. 


\subsection{Datasets for the chemical characteristics of individual waste fractions}

Individual waste fractions were chemically characterized in terms of moisture content, heating values, and organic element content. Fractional moisture content was compiled from 11 Chinese cities (Table S2 in the supporting information). Fractional heating values and organic element content were obtained from five literature sources (Table S3 and Table S4 in the supporting information). As these data were collected from a large number of researches, the sampling and analysis process were not unified and lead to large variation of the results. To limit the effect of extreme data, the median values, instead of average values, were used to represent the statistical results of the chemical characteristics of individual waste fractions, which were summaries together with standard errors in Table 2 used as the dataset for calculating chemical waste compositions in developing countries (named "CN datasets").

For comparison, a dataset of chemical characteristics of individual waste fractions in developed countries was compiled. As a widely used tool for life cycle assessment of waste management, the EASETECH software (Clavreul et al., 2014) contained a comprehensive dataset regarding household waste in Denmark. The Danish waste was divided into more fractions (48 fractions) in comparison to the Chinese case (eight fractions). The 48 waste fractions in the Danish datasets (named "sub-fractions") were merged into eight waste fractions corresponding to those in the Chinese study, to allow for comparison. The chemical characteristics of eight waste fractions (named "DK datasets," as shown in Table 2) were calculated according to eq.1 and eq.2 by combining the chemical characteristics of the sub-fractions (Table S5 in the supporting information) and the distributions of sub-fractions in each of the eight waste fractions (Table S6 in the supporting information).

$$
W F_{m c, j}=\sum_{i}\left(W S F_{m c, i} \times W_{i, j}\right)
$$

where $W F_{m c, j}$ is the moisture content of waste fraction $j$ on a wet weight basis, $\%$ of wf (wet waste fraction); $W S F_{m c . i}$ is the moisture content of the sub-fractions $i$ on a wet weight basis, $\%$ of wsf (wet sub-fraction); and $W_{i, j}$ is the distribution of sub-fraction $i$ in waste fraction $j$ on a wet weight basis, $\%$ of wf. 


$$
W S F_{k, j, d r y}=\frac{\sum_{i}\left[W S F_{k, i, d r y} \times\left(1-W S F_{m c . i}\right) \times W_{i, j}\right]}{\sum_{i}\left[\left(1-W S F_{m c, i}\right) \times W_{i, j}\right]}
$$

146 where $W F_{k, j, d r y}$ is chemical characteristics $k$ (i.e. heating values and organic element content) of

147 waste fraction $j$ on a dry weight basis, \% of df (dry waste fraction); and $W S F_{k, i, d r y}$ is chemical

148 characteristics $k$ of sub-fraction $i$ on a dry weight basis, $\%$ of dsf (dry sub-fraction).

\subsection{Estimation of chemical waste compositions}

The chemical compositions of mixed waste were calculated using the chemical

151 characteristics of individual waste fractions and fractional waste compositions according to

152 equations eq.3 and eq.4.

$$
M W_{m c}=\sum_{j}\left(W F_{m c, j} \times W_{j}\right)
$$

154 datasets and DK datasets) were more reliable for estimating the chemical compositions of

164 Chinese waste, actual values were used as the baseline and the difference in percentage terms 165 between actual and estimated values were calculated according to eq.5 (for moisture content),

where $M W_{m c}$ is the moisture content of mixed waste on a wet weight basis, $\%$ of ww (wet waste); and $W_{j}$, represents the distribution of waste fraction $j$ of mixed waste on a wet weight basis, $\%$ of ww (Table 1).

where $M W_{k, d r y}$ is chemical characteristics $k$ (i.e. heating values and organic element content) of mixed waste on a dry weight basis, $\%$ of dw (dry waste).

\subsection{Comparison of the estimated chemical compositions using $\mathrm{CN}$ and}

\section{DK datasets}

To identify which datasets for the chemical characteristics of individual fractions $(\mathbf{C N}$ eq.6 (for LHV, lower heating value), and eq.7 (for HHV, higher heating value, and organic 
167

168

169

170

171

172

174

element content), respectively. The actual values referred to the laboratory-analyzed chemical compositions of mixed waste according to the existing literature, which were available for Beijing (Wang and Wang, 2013), Chongqing (Huang et al., 2003), Shanghai (Zhang et al., 2009), and Tianjin (He et al., 2010).The estimated values of these four Chinese cities were calculated based on $\mathbf{C N}$ and DK datasets. The actual values and estimated values were both presented in

\section{Table 3.}

$$
D V_{m c}=\frac{M W_{m c}(C N)-M W_{m c}(L A)}{M W_{m c}(L A)} \times 100 \% \text { and } \frac{M W_{m c}(D K)-M W_{m c}(L A)}{M W_{m c}(L A)} \times 100 \%
$$

where $D V_{m c}$ represents the difference in percentage terms between the estimated and actual values of the moisture content of mixed waste, \%; $M W_{m c}(C N)$ and $M W_{m c}(D K)$ represent the estimated moisture content of mixed waste on a wet weight basis, using the $\mathrm{CN}$ and DK datasets, respectively, \% of ww; and $M W_{m c}(L A)$ represents the laboratory-analyzed moisture content of mixed waste on a wet weight basis, \% of ww.

$$
D V_{L H V}=\frac{M W_{L H V}(C N)-M W_{L H V}(L A)}{M W_{L H V}(L A)} \times 100 \% \text { and } \frac{M W_{L H V}(D K)-M W_{L H V}(L A)}{M W_{L H V}(L A)} \times 100 \%
$$

where $D V_{L H V}$ represents the difference in percentage terms between the estimated and actual values of the LHV of mixed waste, \%; $M W_{L H V}(C N)$ and $M W_{L H V}(D K)$ represent the estimated LHV of mixed waste on a wet weight basis, using the $\mathbf{C N}$ and DK datasets, respectively, \% of ww; and $M W_{L H V}(L A)$ represents the laboratory-analyzed LHV of mixed waste on a wet weight basis, $\%$ of ww.

$$
D V_{k}=\frac{M W_{k, d r y}(C N)-M W_{k, d r y}(L A)}{M W_{k, d r y}(L A)} \times 100 \% \text { and } \frac{M W_{k, d r y}(D K)-M W_{k, d r y}(L A)}{M W_{k, d r y}(L A)} \times 100 \%
$$

where $D V_{k}$ represents the difference in percentage terms between the estimated and actual values for the HHV and organic element content of mixed waste, $\% ; M W_{k, d r y}(C N)$ and $M W_{k, d r y}(D K)$ represent the estimated HHV and organic element content of mixed waste on a dry weight basis, using the $\mathbf{C N}$ and $\mathbf{D K}$ datasets, respectively, \% of dw; and $M W_{k, d r y}(L A)$ represents the laboratory-analyzed HHV and organic element content of mixed waste on a dry weight basis, \% 
of dw.

\subsection{Identification of the key chemical characteristics of individual waste}

194

195

196

197

198

199

200

\section{fractions}

To identify the key chemical characteristics of individual fractions impacting on the estimation of chemical composition, the contributions of different chemical characteristics (except for HHV) of individual waste fractions between the $\mathbf{C N}$ and DK datasets and the total wet weight in four Chinese cities (i.e. Beijing, Chongqing, Shanghai, and Tianjin) were calculated according to eq.8 (for moisture content) and eq.9 (for organic elements). The results are shown in Table 4 as a range of the minimum and maximum value calculated for the four cities and discussed in Section 3.3

$$
C T B_{m c, j}=W_{j} \times\left|\left[W F_{m c, j}(C N)-W F_{m c, j}(D K)\right]\right|
$$

where $C T B_{m c, j}$ is the contribution of the difference between the moisture content of waste fractions $j$ in the $\mathbf{C N}$ and DK datasets and the total waste weight, \% of ww; and $W F_{m c, j}(C N)$ and $W F_{m c, j}(D K)$ represent the moisture content of the waste fraction $j$ on a wet weight basis in the CN dataset and DK dataset (Table 2), respectively.

$$
C T B_{k, j}=W_{j} \times\left[1-W F_{m c, j}(L A)\right] \times\left|\left[W F_{k, j, d r y}(C N)-W F_{k, j, d r y}(D K)\right]\right|
$$

where $C T B_{k, j}$ is the contribution of the difference between organic element $k$ of waste fraction $j$ in the $\mathbf{C N}$ and $\mathbf{D K}$ datasets and the total waste weight, $\%$ of ww; $W F_{m c, j}(L A)$ is the laboratory-analyzed moisture content of waste fraction $j$ (Table S2); and $W F_{k, j, d r y}(C N)$ and $W F_{k, j, d r y}(D K)$ represent the content for organic element $k$ of waste fraction $j$ on a dry weight basis in the $\mathbf{C N}$ datasets and DK datasets (Table 2), respectively. 


\subsection{Regional variance of fractional compositions}

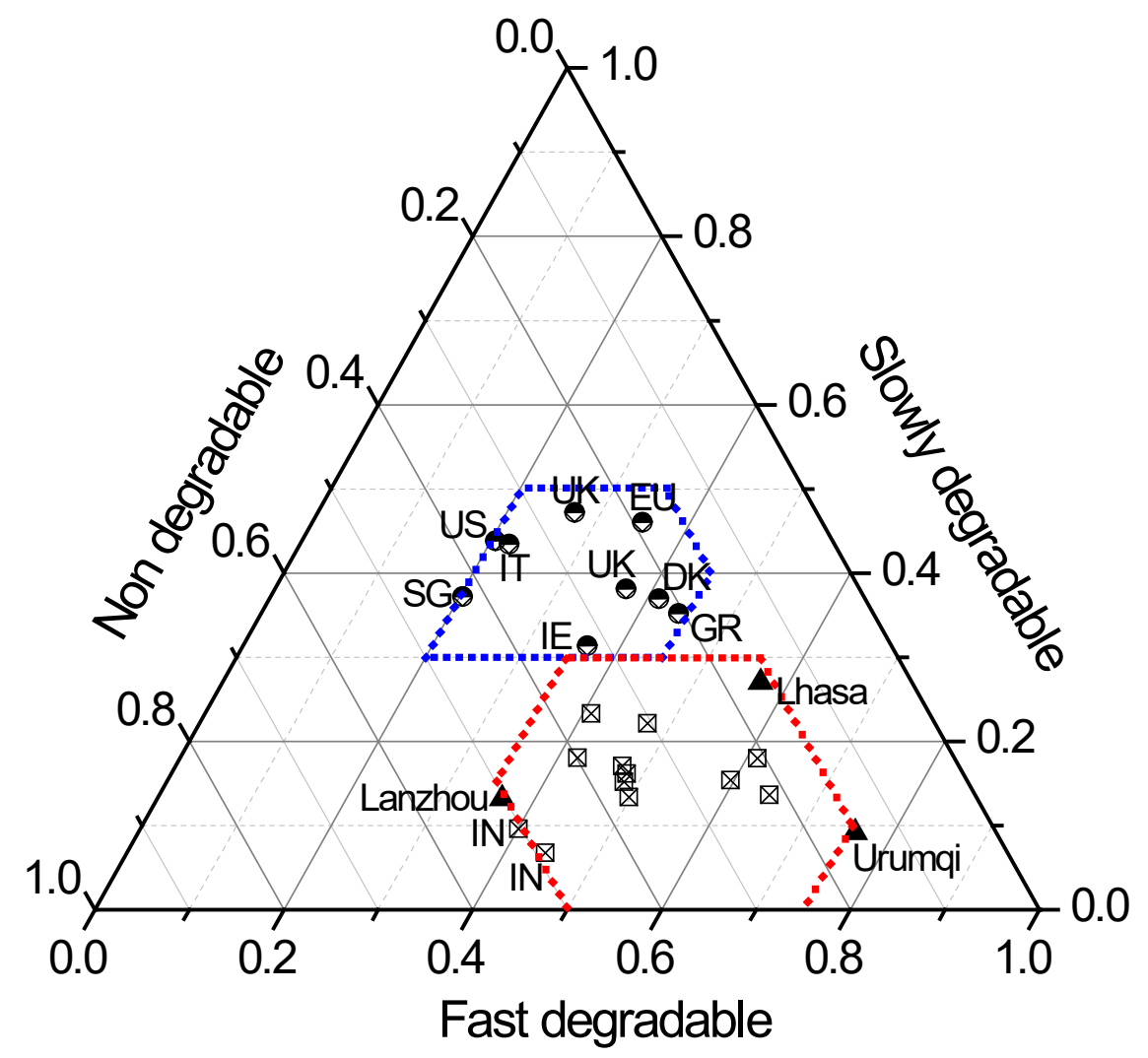

$\Delta$ Chinese cities $\bullet$ Developed countries $\otimes$ Other developing countries

216 Figure 1 Comparison of fractional waste compositions in China and other countries. The blue

217 and red dotted lines represent the ranges of fractional compositions for developed countries and

218 developing countries, respectively. US, EU, UK, IT, DK, GR, IE, SG, and IN are abbreviations

219 for the United States of America, European Union, United Kingdom, Italy, Denmark, Greece,

220 Ireland, Singapore, and India.

Figure 1 compares fractional waste compositions between China and other developing 223 countries as well as with developed countries. The data are clearly clustered in two groups,

224 representing China and developing countries in one cluster and developed countries in another 225 cluster. Non-degradable fractions (including plastics, non-combustibles, glass, and metal) 
contributed similarly in developed and developing countries but showed a large variation, ranging between $15 \%$ and $50 \%$. The main difference, however, was the allocation of slowly degradable fractions (including paper, wood, and textiles) and fast degradable waste fractions (i.e. food waste). The greatest divergence occurred for slowly degradable fractions, where the contribution to total wet weight was more than $30 \%$ in developed countries and less than $30 \%$ in developing countries. Correspondingly, the ratios of fast degradable fractions also differed a lot, i.e. $20 \%$ to $45 \%$ in developed countries and $35 \%$ to $75 \%$ in developing countries. On the basis of previous studies (He et al., 2010; Shenzhen Environmental Sanitary Management Department, 2011), the paper fractions of MSW in Chinese cities mainly consisted of toilet paper or tissue paper. A study about the degradation features of individual waste fractions demonstrated that toilet paper possessed degradability similar to most of the food waste fractions, which were significantly higher than green waste and newspapers (Zheng et al., 2013). Therefore, if toilet papers were accounted for as a fast degradable fraction, the already high contributions of fast degradable fractions in China would be even higher than in developed countries.

Focusing on waste fraction distributions in Chinese cities (Table 1), two common features existed: 1) The fraction of food waste was the largest fraction contributing to the composition of MSW, which often accounted for more than $50 \%$ in weight in most cities. This is attributed to the large share that food consumption has of the total household consumption expenditure (i.e. around 30\% (National Bureau of Statistics of the People's Republic of China, 2015)), but also to the simple packaging and transportation system for food materials. On the one hand, the simple packaging reduces paper and plastic waste fractions. On the other hand, the less packaging and

247 low degree of organization will induce more food wastage during transportation to the consumer 248 (e.g. the outer parts of vegetables are usually inedible and are discarded as waste). 2) The 249 fractions of recyclables (i.e. wood, textiles, glass, and metal) were significantly lower. For 250 instance, each recyclable fraction contributed less than $5 \%$, and the sum of the four recyclables 251 contributed no more than $10 \%$. This could be explained by effective household recovery 252 performance and the existence of waste scavengers (Zhang et al., 2010). 3) The fraction that 253 showed the most variation between the 18 Chinese cities was non-combustibles, which was less 
than 3\% in Suzhou, Shenzhen, Shanghai, Dalian, Chengdu, and Tianjin, but higher than 20\% in 255 Hefei, Harbin, Wuhan, and Lanzhou. The large variation can be attributed mainly to the 256 difference in energy infrastructure. In Hefei, Harbin, Wuhan, and Lanzhou, heating-supplying is 257 necessary in winter, however, the central heating systems were lacked in Wuhan and Hefei, or 258 with limited coverage area in Lanzhou and Harbin. Coal-fired separate heating system existed in 259 those cities due to its low technology and cost requirement, and lack of nature gas network (Gou 260 et al., 2012). Those separate heating system generate large amount of slag and the slag goes into 261 household waste management system.

\subsection{Comparison of estimated chemical waste compositions, using the $\mathrm{CN}$} and DK datasets
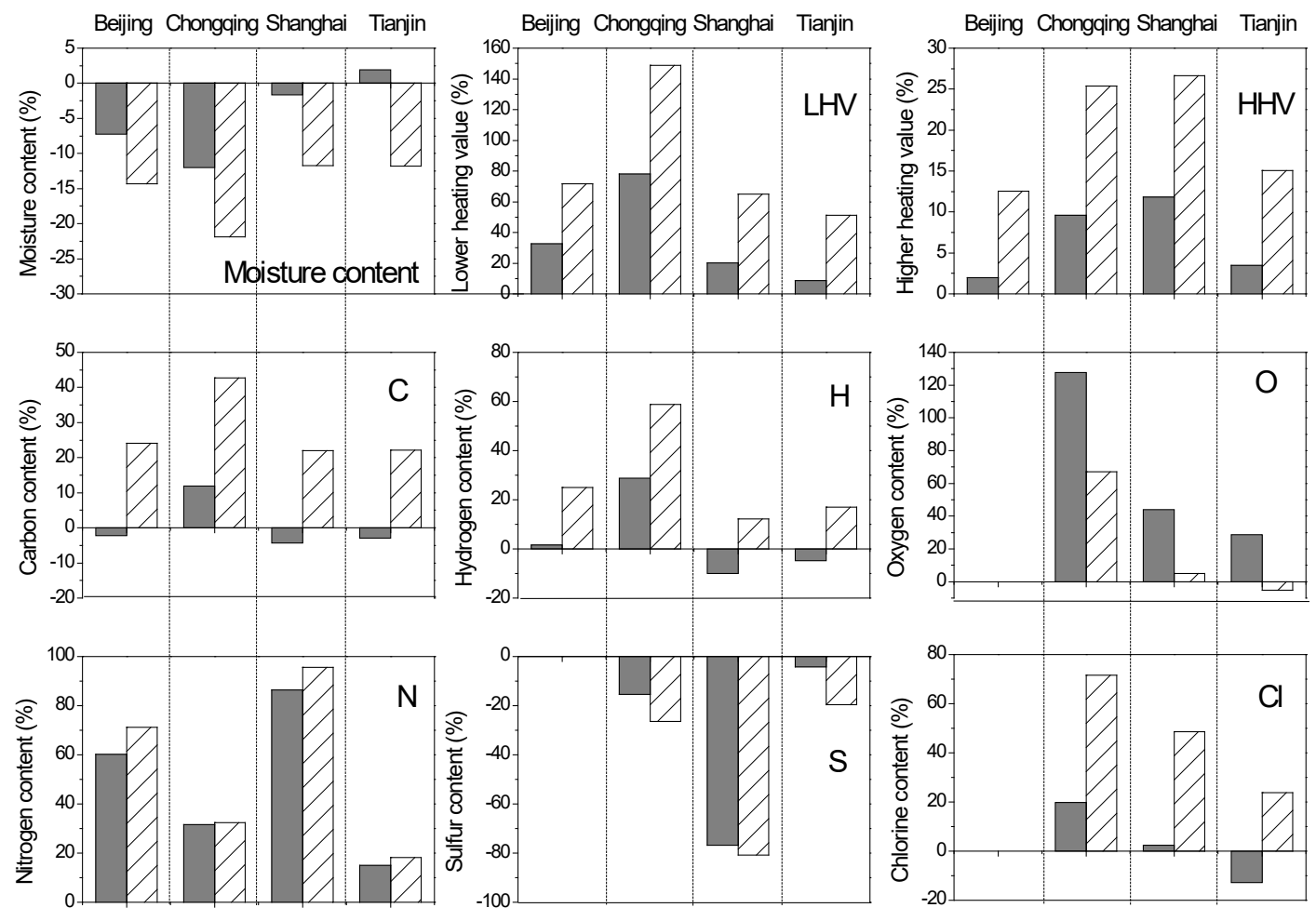

CN database

$\measuredangle \triangle \mathrm{DK}$ database

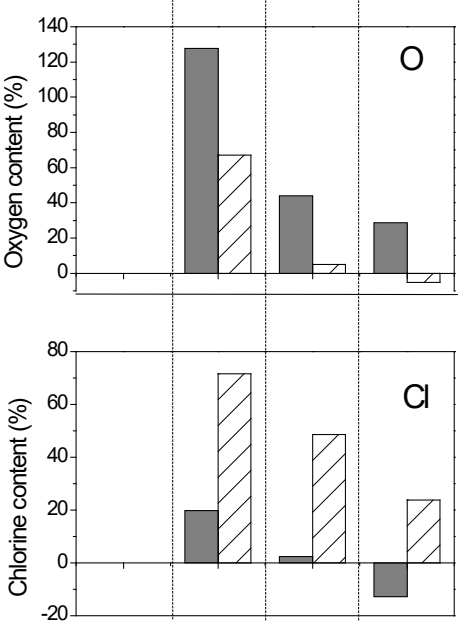

Figure 2 Difference in percentage terms between the estimated chemical compositions and laboratory-analyzed values in four Chinese cities.

Figure 2 presents a comparison of the chemical compositions (moisture content, LHV, HHV, carbon, hydrogen, oxygen, nitrogen, sulfur, and chlorine) of mixed waste. The comparison is 
shown as the difference in percentage terms between actual values based on the laboratory 271 analysis of mixed waste and estimated values calculated based on $\mathrm{CN}$ datasets (gray columns) 272 and DK datasets (white columns). For the frequently used parameters, including moisture content, 273 higher heating values (HHV), carbon content, and hydrogen content, the discrepancies between 274 estimated values using $\mathbf{C N}$ datasets and the actual values were mostly less than $15 \%$. However, 275 discrepancies using the DK datasets were as high as $10 \%$ to $40 \%$. Considering nitrogen, sulfur, and chlorine content, the difference between estimated and actual values varied significantly 277 among the cities, and could be as high as $80 \%$ in Shanghai. This could be explained by their 278 lower weight in mixed waste (i.e. less than $2 \%$ of dry weight), implying the lower the 279 contributions in waste weight, the higher the divergences and uncertainties for estimation. 280 Nevertheless, the higher representativeness of the $\mathbf{C N}$ datasets was also apparent for those three 281 elements.

282 The only exception was for oxygen content in Chongqing, Shanghai, and Tianjin, where the 283 difference between estimation results using $\mathbf{C N}$ datasets and the actual value were one, eight, and 284 five times higher than the estimation results using DK datasets. This could be attributed to the 285 lack or low quality of original data for oxygen in the $\mathbf{C N}$ datasets, which limited representation 286 of oxygen element in the $\mathbf{C N}$ datasets. Even for the reported values, they were not directly 287 analyzed in the laboratory but were estimated by subtracting other element contents from total 288 VS.

289 In order to design a proper MSW treatment strategy, LHV is an important parameter, due to 290 its direct link to potential energy recovery. However, discrepancies between the estimated and 291 actual results were extremely high, namely $9 \% \sim 78 \%$ using the $\mathbf{C N}$ datasets and $50 \% \sim 150 \%$ 292 using the DK datasets, because LHV was not an originally tested value but was instead 293 calculated from HHV and moisture content, and thus the discrepancy was a combination of 294 uncertainty between the latter two parameters. 
3.3 Key chemical characteristics of individual fractions influencing chemical composition estimation

The contributions of the different chemical characteristics of individual waste fractions between the $\mathbf{C N}$ and $\mathbf{D K}$ datasets in relation to the total waste weight in four Chinese cities (i.e. Beijing, Chongqing, Shanghai, and Tianjin) are presented in Table 4 (detailed information shown in Table S7). Divergences were found to be over $1 \%$ of the total waste weight for the moisture content of food waste, paper, textiles, and plastics, the carbon content of food waste, as well as the oxygen content of plastics. These chemical characteristics of waste fractions were key parameters during the chemical waste composition estimations, and so special attention should be paid during data collection. The reason why the above parameters between the $\mathbf{C N}$ and $\mathbf{D K}$ datasets show large differences will be discussed in the following.

\subsubsection{Moisture diffusion}

In Chinese cities, the moisture content of paper, plastic, wood, textiles, and non-combustible fractions was significantly higher than in Denmark (Table 2). This could be attributed the higher proportions of food waste fractions $(>50 \%)$ in China. Owing to the extremely high moisture content (often around 80\%) of food waste, water contained in food scraps would diffuse into other fractions, i.e. paper, wood, ashes, slag, and textiles, when individual fractions were mixed in waste bins and collection vehicles. In China, because of the effective household recovery performance of office paper and cardboard, the fractions of paper in mixed waste were often toilet paper, sanitary towels, and diapers (Shenzhen Environmental Sanitary Management Department, 2011), which possessed high absorption capacities. In the

316 case of fractions of plastic, shopping bags and disposable dishware were commonly found 317 (Shenzhen Environmental Sanitary Management Department, 2011), on which large amounts of 318 oil and food scraps were often stuck. When researchers analyzed the waste properties, they 319 usually sample mixed waste from waste bins or from treatment plants, sort fractions, and then 320 tested the weight and chemical characteristics of individual fractions. However, the distributions 321 of waste fractions obtained by this approach differed from the waste fractions originally generated in households (Dahlén and Lagerkvist, 2008; Sfeir et al, 1999). For example, the 
percentages of paper, wood, textiles, plastics, and non-combustibles would be overestimated and

324 food waste fractions underestimated. A scheme illustrating this issue is shown in Figure S1.

In Denmark, water diffusion from food waste into other fractions is not as obvious as in 326 China, since there is not so much food waste in mixed waste (around $40 \%$ in wet weight). Thus, 327 the moisture content of individual fractions in DK datasets could be considered closer to the original generation (Edjabou et al., 2015). Therefore, when we utilize the fraction waste compositions after mixing (city-specific values seen in Table 1) and the chemical characteristics

330 of individual fractions before mixing (DK datasets seen in Table 2) for estimating chemical compositions, a mismatch occurs and results in an underestimation of the moisture content of mixed waste.

\subsubsection{Carbon content of food waste}

The average carbon content of food waste fractions in Chinese cities was $36.8 \%$, which was significantly lower than the values in Denmark (49.5\%) as well as other developed countries (42.1\% to $50.8 \%$ as shown in Table $\mathbf{S 8}$ in the supporting information). This could be explained by the consumption and dietary customs of Chinese citizens: 1) Vegetables and grains, rather than animal food, make up the main food supply in Chinese households. This is consistent with the lower $\mathrm{C} / \mathrm{O}$ ratios of food waste in China ( 0.91 and 0.98 based on the data in Table S4 in the supporting information) than in developed countries (around 1.28 to 1.40 as shown in Table S8 in the supporting information), since vegetables are mainly composed of carbohydrate, while meat is made up of protein and lipid. 2) Food supplied in Chinese markets is often not cleaned or packaged, e.g. the outer leaves of cabbage, the roots of celery, and the bones of fish and meat are usually sold together with the products. Thus, people have to clean those parts before or after cooking, which, along with high ash content, will be added to the MSW stream and indirectly decrease the carbon content of food waste fractions in Chinese waste.

\subsubsection{Oxygen content of plastics}

The oxygen content of plastics in $\mathrm{CN}$ datasets was $22.3 \%$ of $\mathrm{df}$, which was twice as high as the data in DK datasets $(9.0 \%$ of $\mathrm{df})$. Simultaneously, the $\mathrm{C} / \mathrm{O}$ ratio of plastics in $\mathrm{CN}$ datasets was 2.7 , which was significantly lower than the data in DK datasets (7.4). These features were 
also found for the oxygen content of paper, wood, textile in different levels. The pure paper, wood, textile and plastics were agriculture and industrial products with similar standard in the world. The element compositions of those goods should not differ a lot between the two countries. Thus, the high oxygen content of those waste fractions could be attributed to the pollution of food waste, which was the essential difference between Chinese waste and Danish waste. This assumption was confirmed by our personal experience during waste sampling: food scraps were often found stuck on shopping bags, disposable dishware, as well as tissue paper in

358 household waste bins, and food waste could also stuck on other waste fractions during waste collection and transportation.

\section{Conclusion}

The fast degradable fraction consisting of food waste was the dominant waste fraction in Chinese MSW (> $50 \%$ of ww), as was also the case for other developing countries. This was different from developed countries, where waste was found mainly to consist of slowly degradable (paper, wood, and textiles) and non-degradable fractions (plastics, non-combustibles, glass, and metal). Moisture content in mixed waste in China was usually higher than the values in developed countries. Also, a higher moisture content for individual waste fractions was seen for China, which is due to the diffusion of water from the high content of food waste into other waste fractions like paper, plastics, etc. Adhered food waste caused notable high moisture

369 content and oxygen content for plastic fractions in Chinese waste. In addition, the carbon content 370 of food waste in China was significantly lower than in developed countries, due to diverse 371 consumption and dietary habits. All of these divergences of MSW between China and developed 372 countries will result in differences in engineering and chemical behaviors as well as pollution 373 potentials during waste treatment processes. Therefore, it is not always a reliable practice to 374 estimate waste properties in developing countries by using data sources for the chemical characteristics of individual waste fractions obtained from developed countries, which has been

376 done frequently by researchers till now. If one intends to estimate waste properties in developing 377 countries, it is recommended to obtain not only waste fraction compositions, but also the 
378 moisture content of each fraction in the specific scenario-at the very least. If it is impossible to 379 test chemical characteristics of individual fractions in the specific scenario, the dataset 380 summarized in this study, based on Chinese waste, could be referred to by practitioners.

\section{Acknowledgement}

The work thanks the support from National Environmental Protection Standard Project 383 (2015-4), and Shanghai Technical Standard Projects (14DZ0501500, DB31ZB5-15043). 


\section{Tables}

Table 1 Fractional waste compositions and moisture content of MSW collected in 18 Chinese cities

\begin{tabular}{|c|c|c|c|c|c|c|c|c|c|c|c|c|c|}
\hline \multirow[b]{2}{*}{ City } & \multicolumn{8}{|c|}{ Waste fraction distributions $\left(\%\right.$ of $\left.w^{a}{ }^{a}\right)$} & \multirow{2}{*}{$\begin{array}{l}\text { Moisture } \\
\text { content } \\
(\% \text { of } w w)\end{array}$} & \multicolumn{3}{|c|}{ Sampling description } & \multirow[b]{2}{*}{ Reference } \\
\hline & $\begin{array}{l}\text { Food waste } \\
\qquad\left(\mathrm{FD}^{\mathrm{b}}\right)\end{array}$ & $\begin{array}{l}\text { Paper } \\
\left(\mathrm{SD}^{\mathrm{b}}\right)\end{array}$ & $\begin{array}{l}\text { Wood } \\
\text { (SD) }\end{array}$ & $\begin{array}{c}\text { Textiles } \\
\text { (SD) }\end{array}$ & $\begin{array}{c}\text { Plastics } \\
\left(\mathrm{ND}^{\mathrm{b}}\right)\end{array}$ & $\begin{array}{l}\text { combustibles } \\
\text { (ND) }\end{array}$ & $\begin{array}{l}\text { Glass } \\
\text { (ND) }\end{array}$ & $\begin{array}{l}\text { Metal } \\
(\mathrm{ND})\end{array}$ & & Sample origin & Frequency $\left(n^{c}\right)$ & Time & \\
\hline Beijing & 66.2 & 10.9 & 3.3 & 1.2 & 13.1 & 3.9 & 1.0 & 0.4 & 63.3 & N.A. ${ }^{d}$ & N.A. & 2008 & $\begin{array}{l}\text { (Wang and } \\
\text { Wang, 2013) }\end{array}$ \\
\hline Chengdu & 65.7 & 13.0 & 0.9 & 2.5 & 12.0 & 2.1 & 0.8 & 2.9 & 57.3 & $\begin{array}{l}\text { Waste collection vehicles } \\
\text { in a landfill site }\end{array}$ & One sampling campaign & 2002 & $\begin{array}{l}\text { (Huang and } \\
\text { Liu, 2012) }\end{array}$ \\
\hline Chongqing & 59.2 & 10.1 & 4.2 & 6.1 & 16.0 & -- & 3.4 & 1.1 & 64.1 & $\begin{array}{c}1 \text { residental area and two } \\
\text { landfill sites }\end{array}$ & One sampling campaign & 2002 & $\begin{array}{c}\text { (Huang et al., } \\
\text { 2003) }\end{array}$ \\
\hline Dalian & 63.7 & 8.8 & 0 & 2.0 & 18.6 & 1.2 & 5.0 & 0.8 & 59.7 & $\begin{array}{l}29 \text { garbage bins in } \\
\text { residental area }\end{array}$ & $\begin{array}{l}\text { Twice per month for } 1 \\
\text { year (12 sampling } \\
\text { campaigns) }\end{array}$ & $2004-05$ & (Zhao, 2006) \\
\hline Guangzhou & 53.4 & 8.3 & 1.7 & 10.0 & 18.6 & 6.2 & 1.4 & 0.4 & 55.6 & N.A. & N.A. & 2004-09 & (Chen, 2011) \\
\hline Hangzhou & 64.5 & 6.7 & 0.1 & 1.2 & 10.1 & 15.1 & 2.0 & 0.3 & 56.5 & $\begin{array}{l}40 \text { garbage bins in } \\
\text { residental area }\end{array}$ & One sampling campaigns & 2006 & $\begin{array}{c}\text { (Zhuang et al., } \\
\text { 2008) }\end{array}$ \\
\hline Harbin & 44.8 & 13.4 & 0.0 & 4.7 & 3.3 & 24.5 & 6.6 & 2.7 & 54.8 & $\begin{array}{l}\text { Garbage bins in } \\
\text { residental area }\end{array}$ & One sampling campaign & 2007 & (Xie, 2009) \\
\hline Hefei & 61.5 & 1.9 & 0.9 & 2.1 & 11.4 & 21.7 & 0.6 & -- & 52.5 & 5 transfer stations in & N.A. & 2005 & $(\mathrm{Jin}, 2006)$ \\
\hline
\end{tabular}




\begin{tabular}{|c|c|c|c|c|c|c|c|c|c|c|c|c|c|}
\hline & & & & & & & & & & residental area & & & \\
\hline Lanzhou & 36.5 & 9.7 & 1.4 & 2.1 & 11.3 & 37.8 & 0.9 & 0.2 & 44.3 & $\begin{array}{c}\text { Unloading places in } 5 \\
\text { landfill sites }\end{array}$ & $\begin{array}{l}\text { One time in winter and } \\
\text { one time in summer ( } 2 \\
\text { sampling campaigns) }\end{array}$ & 2006 & $(\mathrm{Ji}, 2007)$ \\
\hline Lhasa & 57.0 & 6.0 & 14.0 & 7.0 & 12.0 & 3.0 & 0.0 & 1.0 & 46.7 & $\begin{array}{l}\text { Unloading place in a } \\
\text { landfill site }\end{array}$ & $\begin{array}{l}\text { Twice per season for } 1 \\
\text { year ( } 8 \text { sampling } \\
\text { campaigns) }\end{array}$ & 2006 & $\begin{array}{c}\text { (Jiang et al., } \\
\text { 2009) }\end{array}$ \\
\hline Qingdao & 69.0 & 9.5 & 2.3 & 3.0 & 8.4 & 6.8 & 2.2 & 0.9 & 56.0 & $\begin{array}{c}30 \text { garbage bins in } \\
\text { residental area }\end{array}$ & $\begin{array}{l}\text { Once per month for } 1 \\
\text { year (12 sampling } \\
\text { campaigns) }\end{array}$ & 2009 & $\begin{array}{c}\text { (Jiang et al., } \\
\text { 2011) }\end{array}$ \\
\hline Shanghai & 63.8 & 11.1 & 1.1 & 2.6 & 17.2 & 1.1 & 2.7 & 0.4 & 58.7 & $\begin{array}{c}36 \text { garbage bins in } \\
\text { residental area }\end{array}$ & $\begin{array}{l}\text { Twice per month for } 1 \\
\text { year ( } 24 \text { sampling } \\
\text { campaigns) }\end{array}$ & 2008-09 & $\begin{array}{c}\text { (Zhang et al., } \\
\text { 2009) }\end{array}$ \\
\hline Shenyang & 60.4 & 7.9 & 2.5 & 3.6 & 12.9 & 5.3 & 5.4 & 2.1 & 61.8 & $\begin{array}{l}\text { Unloading place in a } \\
\text { landfill site }\end{array}$ & $\begin{array}{l}\text { Twice per month for } 1 \\
\text { year ( } 24 \text { sampling } \\
\text { campaigns) }\end{array}$ & 2008 & $(\mathrm{Ma}, 2010)$ \\
\hline Shenzhen & 51.1 & 17.2 & 3.9 & 2.7 & 21.8 & 0.8 & 2.1 & 0.4 & 59.7 & $\begin{array}{l}2 \text { landfill sites and } 3 \\
\text { incineration plants }\end{array}$ & One sampling campaign & 2011 & $\begin{array}{l}\left(\mathrm{SZESMD}^{\mathrm{e}},\right. \\
\text { 2011) }\end{array}$ \\
\hline Suzhou & 62.6 & 10.9 & 0.9 & 4.2 & 18.6 & 0.7 & 2.0 & 0.2 & 60.7 & $\begin{array}{c}1 \text { transfer station in } \\
\text { residental area }\end{array}$ & $\begin{array}{c}\text { Twice every } 2 \text { month for } \\
1 \text { year (12 sampling } \\
\text { campaigns) }\end{array}$ & 2007 & $\begin{array}{c}\text { (He et al., } \\
2008)\end{array}$ \\
\hline Tianjin & 56.9 & 15.3 & 1.6 & 3.9 & 16.9 & 2.9 & 1.6 & 0.7 & 55.0 & $\begin{array}{c}5 \text { transfer stations in } \\
\text { residental area }\end{array}$ & $\begin{array}{c}6 \text { times in April (6 } \\
\text { sampling campaigns) }\end{array}$ & 2009 & $\begin{array}{c}\text { (He et al., } \\
\text { 2010) }\end{array}$ \\
\hline
\end{tabular}




\begin{tabular}{|c|c|c|c|c|c|c|c|c|c|c|c|c|c|}
\hline Urumqi & 76.0 & 2.4 & 2.5 & 4.2 & 5.4 & 6.4 & 2.4 & 0.8 & 47.0 & 1 treatement plant & $\begin{array}{c}8 \text { times per month for } 1 \\
\text { year (96 sampling } \\
\text { campaigns) }\end{array}$ & $2007-08$ & $\begin{array}{c}\text { (Shao et al., } \\
2009 \text { ) }\end{array}$ \\
\hline Wuhan & 55.3 & 1.5 & 8.3 & 0.0 & 4.5 & 27.3 & 2.0 & 1.1 & 53.5 . & N.A. & N.A. & 2008 & $(\mathrm{Li}, 2010)$ \\
\hline
\end{tabular}

${ }^{\mathrm{a}} \mathrm{ww}$, wet waste.

${ }^{b} \mathrm{FD}, \mathrm{SD}$, and ND represent the fast, slowly, and non- degradable fraction groups, respectively.

${ }^{\mathrm{c}} n$, number of sampling campaigns.

${ }^{\mathrm{d}}$ N.A. not available.

e SZESMD, Shenzhen Environmental Sanitary Management Department. 
Table $2 \mathrm{CN}$ and $\mathrm{DK}$ datasets for chemical characteristics of individual waste fractions (based on Table S2, Table S3, and Table S4 for CN datasets, and Table S5 and Table S6 for DK datasets)

\begin{tabular}{|c|c|c|c|c|c|c|c|c|}
\hline \multirow{2}{*}{ Waste fraction } & \multirow{2}{*}{$\begin{array}{l}\text { Moisture content } \\
\qquad\left(\% \text { of } \mathrm{wf}^{\mathrm{a}}\right)\end{array}$} & \multirow{2}{*}{$\begin{array}{c}\text { HHV } \\
\left(\mathrm{MJ} / \mathrm{kg} \text { of } \mathrm{df}^{\mathrm{b}}\right)\end{array}$} & \multicolumn{6}{|c|}{ Organic element content ( $\%$ of $d f)$} \\
\hline & & & $\mathrm{C}$ & $\mathrm{H}$ & $\mathrm{O}$ & $\mathrm{N}$ & $\mathrm{S}$ & $\mathrm{Cl}$ \\
\hline \multicolumn{9}{|c|}{$\mathrm{CN}$ datasets } \\
\hline Food waste & $68.0 \pm 5.8^{\mathrm{c}}$ & $16.3 \pm 1.7$ & $36.8 \pm 2.3$ & $5.5 \pm 0.5$ & $38.6 \pm 2.9$ & $2.6 \pm 0.5$ & $0.3 \pm 0.1$ & 0.82 \\
\hline Paper & $43.2 \pm 14.1$ & $16.6 \pm 1.5$ & $41.3 \pm 3.2$ & $5.9 \pm 0.4$ & $44.7 \pm 3.0$ & $0.3 \pm 0.4$ & $0.2 \pm 0.1$ & 0.46 \\
\hline Wood & $48.0 \pm 14.3$ & $18.3 \pm 1.1$ & $42.9 \pm 4.7$ & $6.1 \pm 0.1$ & $42.0 \pm 1.0$ & $1.6 \pm 1.1$ & $0.1 \pm 0.03$ & 0.36 \\
\hline Textiles & $43.5 \pm 18.6$ & $16.5 \pm 2.4$ & $46.3 \pm 2.5$ & $6.6 \pm 0.3$ & $40.8 \pm 2.5$ & $4.4 \pm 3.2$ & $0.5 \pm 0.5$ & 0.46 \\
\hline Plastics & $43.5 \pm 15.2$ & $32.6 \pm 2.4$ & $60.4 \pm 4.0$ & $7.9 \pm 0.5$ & $22.3 \pm 6.2$ & $0.5 \pm 0.7$ & $0.1 \pm 0.05$ & 1.9 \\
\hline Non-combustibles ${ }^{\mathrm{d}}$ & $29.6 \pm 17.8$ & -- & -- & -- & -- & -- & -- & -- \\
\hline Glass & $2.4 \pm 5.7$ & -- & -- & -- & -- & -- & -- & -- \\
\hline Metal & $5.4 \pm 2.6$ & -- & -- & -- & -- & -- & -- & -- \\
\hline \multicolumn{9}{|c|}{ DK datasets } \\
\hline Food waste & 72.2 & 19.8 & 49.9 & 6.9 & 34.4 & 3.1 & 0.23 & 0.82 \\
\hline Paper & 24.9 & 17.6 & 45.5 & 6.3 & 36.2 & 0.44 & 0.08 & 0.13 \\
\hline Wood & 47.6 & 14.4 & 43.9 & 5.5 & 25.4 & 1.8 & 0.22 & 0.24 \\
\hline Textiles & 14.2 & 20.9 & 53.1 & 6.4 & 31.4 & 2.6 & 0.38 & 0.58 \\
\hline Plastics & 9.9 & 30.5 & 67.0 & 9.4 & 9.0 & 0.90 & 0.12 & 3.0 \\
\hline Non-combustibles & 14.8 & 0.91 & 4.0 & 0.58 & 3.0 & 0.25 & 0.11 & 0.43 \\
\hline Glass & 7.2 & 0 & 0 & 0 & 0 & 0 & 0.04 & 0 \\
\hline Metal & 11.0 & 11.7 & 24.5 & 3.8 & 3.6 & 0.18 & 0.02 & 0.04 \\
\hline
\end{tabular}

${ }^{\mathrm{a}}$ wf, wet waste fraction.

${ }^{\mathrm{b}} \mathrm{df}$, dry waste fraction.

${ }^{\mathrm{c}}$ median \pm standard errors.

${ }^{\mathrm{d}}$ Non-combustibles represents ashes, slags, ceramics, and other non-combustible fines. 
Table 3 Chemical waste compositions in four Chinese cities

\begin{tabular}{|c|c|c|c|c|c|c|c|c|c|c|}
\hline \multirow[b]{2}{*}{ City } & \multirow{2}{*}{$\begin{array}{l}\text { Moisture } \\
\text { content } \\
\left(\text { of ww }^{\mathrm{a}} \text { ) }\right.\end{array}$} & \multirow{2}{*}{$\begin{array}{c}\text { LHV } \\
(\mathrm{MJ} / \mathrm{kg} \text { of } \\
\text { ww) }\end{array}$} & \multirow{2}{*}{$\begin{array}{c}\mathrm{HHV} \\
(\mathrm{MJ} / \mathrm{kg} \text { of } \\
\left.\mathrm{dw}^{\mathrm{b}}\right)\end{array}$} & \multicolumn{6}{|c|}{ Organic element content $(\%$ of $\mathrm{dw})$} & \multirow[b]{2}{*}{ Reference } \\
\hline & & & & $\mathrm{C}$ & $\mathrm{H}$ & $\mathrm{O}$ & $\mathrm{N}$ & $\mathrm{S}$ & $\mathrm{Cl}$ & \\
\hline \multicolumn{11}{|c|}{ Laboratory analyzed } \\
\hline Beijing & 63.3 & 4.6 & 17.9 & 39.3 & 5.4 & -- & 1.0 & -- & -- & (Wang and Wang, 2013) \\
\hline Chongqing & 64.1 & 3.7 & 16.8 & 35.5 & 4.4 & 14.3 & 1.3 & 0.24 & 0.72 & (Huang, et al., 2003) \\
\hline Shanghai & 58.7 & 5.5 & 16.9 & 41.8 & 6.3 & 22.5 & 0.85 & 0.85 & 0.90 & (Zhang et al., 2009) \\
\hline Tianjin & 55.0 & 6.3 & 18.1 & 40.9 & 5.9 & 25.3 & 1.3 & 0.2 & 1.0 & (He et al., 2010) \\
\hline \multicolumn{11}{|c|}{ Estimated using $\mathrm{CN}$ dataset } \\
\hline Beijing & 58.7 & 6.1 & 18.2 & 38.4 & 5.5 & 32.9 & 1.6 & 0.20 & 0.85 & \multirow{4}{*}{ This study } \\
\hline Chongqing & 56.4 & 6.6 & 18.3 & 39.8 & 5.6 & 32.6 & 1.7 & 0.20 & 0.86 & \\
\hline Shanghai & 57.7 & 6.6 & 18.8 & 40.0 & 5.7 & 32.4 & 1.6 & 0.20 & 0.92 & \\
\hline Tianjin & 56.1 & 6.8 & 18.6 & 39.7 & 5.6 & 32.5 & 1.5 & 0.19 & 0.87 & \\
\hline \multicolumn{11}{|c|}{ Estimated using DK dataset } \\
\hline Beijing & 54.2 & 7.9 & 20.1 & 48.8 & 6.8 & 24.5 & 1.7 & 0.17 & 1.2 & \multirow{4}{*}{ This study } \\
\hline Chongqing & 50.1 & 9.3 & 21.1 & 50.7 & 6.9 & 23.9 & 1.7 & 0.18 & 1.2 & \\
\hline Shanghai & 51.8 & 9.0 & 21.4 & 51.0 & 7.1 & 23.6 & 1.7 & 0.16 & 1.3 & \\
\hline Tianjin & 48.5 & 9.5 & 20.8 & 50.0 & 6.9 & 24.0 & 1.5 & 0.16 & 1.2 & \\
\hline
\end{tabular}

${ }^{\mathrm{a}} \mathrm{ww}$, wet waste.

b dw, dry waste. 
Table 4 Contributions of the different chemical characteristics of individual waste fractions between CN and DK datasets to the total waste weight (ranges of results in four Chinese cities in Table S7) $\left(\%\right.$ of $\left.w w^{a}\right)$

\begin{tabular}{|c|c|c|c|c|c|c|c|}
\hline & \multirow{2}{*}{ Moisture content } & \multicolumn{6}{|c|}{ Organic element content } \\
\hline & & $\mathrm{C}$ & $\mathrm{H}$ & $\mathrm{O}$ & $\mathrm{N}$ & $\mathrm{S}$ & $\mathrm{Cl}$ \\
\hline Food waste & $2.39 \sim 2.78$ & $1.55 \sim 2.62$ & $0.17 \sim 0.28$ & $0.50 \sim 0.84$ & $0.06 \sim 0.11$ & $0.008 \sim 0.013$ & $0.0002 \sim 0.0004$ \\
\hline Paper & $1.85 \sim 2.81$ & $0.14 \sim 0.33$ & $0.01 \sim 0.03$ & $0.29 \sim 0.68$ & $0.005 \sim 0.011$ & $0.002 \sim 0.005$ & $0.01 \sim 0.03$ \\
\hline Wood & $0.005 \sim 0.018$ & $0.01 \sim 0.02$ & $0.003 \sim 0.014$ & $0.1 \sim 0.43$ & $0.001 \sim 0.005$ & $0.0008 \sim 0.0036$ & $0.0007 \sim 0.0030$ \\
\hline Textiles & $0.35 \sim 1.78$ & $0.06 \sim 0.15$ & $0.002 \sim 0.004$ & $0.09 \sim 0.21$ & $0.02 \sim 0.04$ & $0.0009 \sim 0.0022$ & $0.001 \sim 0.003$ \\
\hline Plastics & $4.41 \sim 5.8$ & $0.48 \sim 0.65$ & $0.11 \sim 0.15$ & $0.96 \sim 1.31$ & $0.03 \sim 0.04$ & $0.004 \sim 0.006$ & $0.08 \sim 0.11$ \\
\hline Non-combustibles & $0.16 \sim 0.58$ & -- & -- & -- & -- & -- & -- \\
\hline Glass & $0.05 \sim 0.16$ & -- & -- & -- & -- & -- & -- \\
\hline Metal & $0.02 \sim 0.06$ & -- & -- & -- & -- & -- & -- \\
\hline
\end{tabular}

${ }^{\mathrm{a}} \mathrm{ww}$, wet waste. 


\section{References}

Chen, X.M., 2011. Methan utilization in municipal solid waste landfill, Environmental Engineering. Jinan University, Guangzhou.

Clavreul, J., Baumeister, H., Christensen, T.H., Damgaard, A., 2014. An environmental assessment system for environmental technologies. Environ. Model. Softw. 60, 18-30.

Cleary, J., 2009. Life cycle assessments of municipal solid waste management systems: A comparative analysis of selected peer-reviewed literature. Environ. Int. 35, 1256-1266.

Dahlén, L., Lagerkvist, A., 2008. Methods for household waste composition studies. Waste Manag. 28, 1100-1112.

Edjabou, M.E., Jensen, M.B., Götze, R., Pivnenko, K., Petersen, C., Scheutz, C., Astrup, T.F., 2015. Municipal solid waste composition: Sampling methodology, statistical analyses, and case study evaluation. Waste Manag. 36, 12-23.

Gou, J.F., Zeng, Z.Z., Ji, A.M., Wang, H., Wang, H.C., 2012. Physical composition and moisture characteristics of municipal solid waste of Lanzhou City. Environmental Engineering 20, 101-105.

He, J.B., Yao, Q.J., Han, Z.M., An, J.J., Liu, K.Q., Tang, Y., Peng, W.G., 2010. Investigation and analysis of domestic waste within the south area of Haihe river in Tianjin Binhai new area. Environmental Sanitation Engineering (In Chinese) 18, 7-10.

He, S., Zhu, S.Y., Yu, L.Q., 2008. Characteristics analysis and treatment countermeasures of domestic waste in Suzhou city. Environmental Sanitation Engineering (In Chinese) 16, 62-64.

Huang, B.S., Li, X.H., Wang, L.A., Cui, Z.Q., 2003. Analysis of physicochemical property and discussion of disposal of MSW in the urban zone of Chongqing city. Journal of Chongqing University (In Chinese) 26, 9-13.

Huang, M.X., Liu, D., 2012. Characteristics and compositions of municipal solid waste in Sichuan Province. Environmental Monitoring in China (in Chinese) $28,121-123$.

Ji, A.M., 2007. The analysis of physical characteristics and incinerating feasibility of municipal solid waste in Lanzhou (in Chinese), Environmental Engineering. Lanzhou University, Lanzhou, China.

Jiang, J.G., Lou, Z.Y., Ng, S., Luobu, C., Ji, D., 2009. The current municipal 
solid waste management situation in Tibet. Waste Manag. 29, 1186-1191.

Jiang, Z., Zhang, W.X., Qi, W.J., 2011. Physical properties and change regularity of domestic waste in Qingdao city. Environmental Sanitation Engineering (In Chinese) 19, 36-41.

Jin, J., 2006. Research on property of household waste in Hefei and bio-waste treated by earthworm (in Chinese). Environmental Engineering, Hefei University of Technology, Hefei, China.

Kaiser, E.R., 1966. Chemical analysis of refuse compounds, National Incinerator Conference. ASME, New York.

Lagerkvist, A., Ecke, H., Christensen, T.H., 2011. Waste generation and characterization: 2.1 Waste characterization: approaches and methods, in: Christensen, T.H. (Ed.), Solid Waste Technoloty \& Management. Blackwell Pulishing Ltd., Chichester, United Kingdom.

Li, L., 2010. Sustainable development research on the urban and rural domestic refuse disposal in Wuhan. Ecological Economy (in Chinese) 5, 156-158.

Ma, Z.Z., 2010. Domestic wasteinvestigation and disposal method in Shenyang city. Environmental Sanitation Engineering (In Chinese) 18, 13-18.

Manfredi, S., Tonini, D., Christensen, T.H., 2011. Environmental assessment of different management options for individual waste fractions by means of life-cycle assessment modelling. Resour. Conserv. Recy. 55, 995-1004.

Ministry of Housing and Urban-Rural Development of the People's Republic of China, (2009) Sampling and analysis methods for domestic waste, Beijing.

National Bureau of Statistics of the People's Republic of China, 2015. China Statistical Yearbook, Beijing.

Ni, N., Hong, G.C., 2005. Physiochemical properties and treatment countermeasure of domestic waste in Hangzhou city. Environmental Sanitation Engineering (In Chinese) 13, 31-36.

Riber, C., Petersen, C., Christensen, T.H., 2009. Chemical composition of material fractions in Danish household waste. Waste Manag. 29, 1251-1257.

Sfeir, H., Reinhart, D.R., McCauley-Bell, P.R., 1999. An evaluation of municipal solid waste composition bias sources. J. Air Waste Manag. Assoc. 49 (9), 1096-1102.

Shao, H.W., Xu, W.L., Kong, J.J., Patiguli, Ge, C.H., Zhang, Y.S., Yu, J., Wei, W., 2009. Investigation and estimation of domestic waste in Urumqi. 
Environmental Sanitation Engineering (In Chinese) 17, 10-12.

Shenzhen Environmental Sanitary Management Department, 2011. Statistical analysis of municipal solid waste characteristics in Shenzhen (in Chinese), Shenzhen, China.

Tai, J., Zhang, W., Che, Y., Feng, D., 2011. Municipal solid waste source-separated collection in China: A comparative analysis. Waste Manag. 31, 1673-1682.

Tchobanoglous, G., Theisen, H., Vigil, S., 1993. Integrated Solid Waste Management: Engineering Principles and Management Issues. McGraw-Hill.

Wang, H., Wang, C.M., 2013. Municipal solid waste management in Beijing: characteristics and challenges. Waste Manag. Res. 31, 67-72.

Wang, H.T., Nie, Y.F., 2001. Municipal solid waste characteristics and management in China. J. Air Waste Manage. Assoc. 51, 250-263.

Wei, J.B., Herbell, J.D., Zhang, S., 1997. Solid Waste Disposal in China-Situation, Problems and Suggestions. Waste Manag. Res. 15, 573-583.

He, J.B., Yao, Q.J., Han, Z.M., An, J.J., Liu, K.Q., Tang, Y., Peng, W.G., 2010. Investigation and analysis of domestic waste within the south area of Haihe river in Tianjin Binhai new area. Environmental Sanitation Engineering (In Chinese) 18, 7-10.

Hu, X.J., Zhang, M., Yu, J.F., Zhang, G.R., 2012, Food waste management in China: status,problems and solutions. Acta Ecologica Sinica. 32(14):4575-4584.

Huang, B.S., Li, X.H., Wang, L.A., Cui, Z.Q., 2003. Analysis of physicochemical property and discussion of disposal of MSW in the urban zone of Chongqing city. Journal of Chongqing University (In Chinese) 26, 9-13.

Wu, Y.C., Xu, L.F., 2013. Analysis of the Barrier Factors of Municipal Solid Waste Classification Recycling. in: Zhao, J., Iranpour, R., Li, X., Jin, B. (Ed.), Advances in Materials Research. Trans Tech Publications Ltd., Zurich, Switzerland. pp: 2618-2621.

Xie, B., 2009. Study on the waste degradation behavior and stabilization of dumping sites in northeasten China (in Chinese), Environmental Science and Engineering Harbin Institute of Technology, Harbin, China.

Yang, N., Zhang, H., Chen, M., Shao, L.M., He, P.J., 2012. Greenhouse gas emissions from MSW incineration in China: Impacts of waste characteristics and energy recovery. Waste Manag. 32, 2552-2560. 
Yang, N., Zhang, H., Shao, L.M., Lü, F., He, P.J., 2013. Greenhouse gas emissions during MSW landfilling in China: Influence of waste characteristics and LFG treatment measures. J. Environ. Manag. 129, 510-521.

Zhang, D.Q., Tan, S.K., Gersberg, R.M., 2010. Municipal solidwastemanagementinChina:Status,problemsandchallenges. J. Environ. Manag. 91, 1623-1633.

Zhang, H., He, P.J., Shao, L.M., 2008. Flow analysis of heavy metals in MSW incinerators for investigating contamination of hazardous components. Environ. Sci. Technol. 42, 6211-6217.

Zhang, Y., Yang, X.H., Wang, X.Y., 2009. Survey Report of MSW Characteristics in Shanghai (in Chinese). Shanghai Institute for Design \& Research on Environmental Engineering, Shanghai, China.

Zhao, W., van der Voet, E., Zhang, Y.F., Huppes, G., 2009a. Life cycle assessment of municipal solid waste management with regard to greenhouse gas emissions: Case study of Tianjin, China. Sci. Total Environ. 407, 1517-1526.

Zhao, W.W., 2006. Survey and analysis of municipal domestic waste in centre area of Dalian city. Environmental Sanitation Engineering (In Chinese) 14, 29-30.

Zhao, Y., Christensen, T.H., Lu, W.J., Wu, H.Y., Wang, H.T., 2011. Environmental impact assessment of solid waste management in Beijing City, China. Waste Manag. 31, 793-799.

Zhao, Y., Wang, H.T., Lu, W.J., Damgaard, A., Christensen, T.H., 2009 b. Life-cycle assessment of the municipal solid waste management system in Hangzhou, China (EASEWASTE). Waste Manag. Res. 27, 399-406.

Zheng, W., Phoungthong, K., Lu, F., Shao, L.M., He, P.J., 2013. Evaluation of a classification method for biodegradable solid wastes using anaerobic degradation parameters. Waste Manag. 33(12), 2632-2642.

Zhuang, Y., Wu, S.W., Wang, Y.L., Wu, W.X., Chen, Y.X., 2008. Source separation of household waste, a case study in China. Waste Manag. 28, 2022-2030. 